\title{
STRATEGI REBRANDING ZORA RADIO
}

\author{
Dini Safitri Istiqomah Bantilan ${ }^{1}$, Roro Retno Wulan², dan Indra N. A. Pamungkas ${ }^{3}$ \\ 1, 2,3 Universitas Telkom
}

\begin{abstract}
ABSTRAK
Persaingan di dunia bisnis yang semakin hari semakin ketat mengharuskan perusahaan-perusahaan untuk terus melakukan upaya agar dapat tetap bertahan di industri yang digelutinya. Radio sebagai salah satu media massa populer di Indonesia juga tidak lepas dari tingginya tingkat persaingan dalam memperebutkan pasar. Meskipun suatu produk telah memiliki merek yang dikenal oleh khalayak luas, titik kejenuhan pada tingkat kedewasaan dalam siklus hidup suatu produk terkadang mengharuskan perusahaan untuk melakukan perubahan-perubahan agar tetap mampu memiliki daya saing. Perubahan yang dilakukan terhadap merek ini dikenal dengan rebranding. Salah satu kasus rebranding pada radio adalah rebranding yang dilakukan oleh Zora Radio. Pada tahun 2014, Zora Radio yang merupakan salah satu radio di Kota Bandung yang melakukan rebranding yang ditandai dengan perubahan segmenting menjadi radio muda. Perubahan ini diikuti dengan perubahan-perubahan lainnya yang tidak terlepas dari proses penetapan strategi dalam pelaksanaan rebranding. Maka dari itu, tujuan dari penelitian ini adalah untuk mengetahui strategi rebranding dari Zora Radio dengan melihat melalui tiga tahapan utama strategi yaitu tahap perencanaan, tahap implementasi, dan tahap evaluasi. Penelitian ini menggunakan metode kualitatif dengan pendekatan studi kasus. Berdasarkan hasil penelitian, tahap perencanaan strategi rebranding Zora Radio dilakukan dengan menetapkan tujuan, identifikasi kekuatan dan kelemahan internal, identifikasi peluang dan ancaman eksternal, serta penetapan jangka waktu bagi strategi. Tahap implementasi diwujudkan melalui empat elemen utama rebranding yaitu repositioning, renaming, redesigning, dan relaunching. Tahap akhir yaitu evaluasi dilakukan dengan memantau feedback dari berbagai sumber.
\end{abstract}

Kata-kata Kunci: Strategi, merek, rebranding, radio, studi kasus

\section{REBRANDING STRATEGY OF ZORA RADIO}

\begin{abstract}
The competition in the business world that is increasingly stringent requires companies to continue to make efforts in order to survive in the industry that they do. Radio as one of the popular mass media in Indonesia can not be separated from the high level of competition in the market. Although a product has had a brand known by a wide audience, the point of saturation on the level of maturity in the life cycle of a product often requires companies to make changes in order to have a competitive edge. Changes made for the brand is known as rebranding. One case of rebranding on the radio is rebranding done by Zora Radio. In 2014, Zora Radio which located in Bandung did rebranding, characterized by changing its segmenting into radio for the youth. This change followed by other changes that can not be separated from the process of determining the strategy in the implementation of the rebranding process. Therefore, the purpose of this study was to determine the rebranding strategy of Zora Radio with a view through three main stages, namely strategic planning phase, implementation phase and evaluation phase. This study used a qualitative method with case study approach. Based on this research, the planning stage rebranding strategy Zora Radio done by setting goals, identifying strengths and weaknesses, identify opportunities and external threats, as well as the determination period of the strategies. The implementation phase is done through four main elements of rebranding, namely repositioning, renaming, redesigning and relaunching. The final stage is an evaluation done by monitoring the feedback from various sources.
\end{abstract}

Keywords: Strategy, brand, rebranding, radio, case study

Korespondensi: Dini Safitri Istiqomah Bantilan, S.Ikom. Program Studi Ilmu Komunikasi, Fakultas Komunikasi dan Bisnis, Universitas Telkom, Jl. Telekomunikasi Terusan Buah Batu, Bandung 40257. Email: dsibantilan@gmail.com

Submitted: May 2017, Accepted: December 2017, Published: December 2017

ISSN: 2528-6927 (printed), ISSN: 2541-3678 (online). Website: http://jurnal.unpad.ac.id/profesi-humas 


\section{PENDAHULUAN}

Perkembangan dunia bisnis saat ini mengharuskan perusahaan-perusahaan yang berkecimpung di dalamnya untuk mampu menghadapi persaingan yang semakin hari semakin ketat. Berbagai upaya dan strategi harus terus dilakukan untuk dapat mempertahankan keberlangsungan hidup perusahaan.

Dalam dunia pemasaran, untuk mampu menentukan strategi yang tepat diperlukan pemahaman mengenai siklus hidup produk atau product life cycle. Dengan memahami siklus daur hidup produk maka akan dapat dipahami mengenai apa saja yang harus dilakukan agar produk dapat memiliki daya saing di pasar bisnisnya.

Ada empat tahapan dalam siklus hidup produk. Yang pertama adalah tahap perkenalan (introduction). Pada tahap ini produk masih baru dan perlu untuk dikenalkan kepada konsumen. Tahap selanjutnya adalah tahap pertumbuhan (growth). Pada tahap ini perusahaan mulai memikirkan strategi untuk melakukan penguasaan pasar sehingga proses distribusi dan promosi terhadap produk semakin ditingkatkan. Selanjutnya adalah tahap kedewasaan (maturity). Tujuan utama dari tahap ini adalah untuk mempertahankan penguasaan pasar dengan tetap memaksimalkan keuntungan yang diraih. Persaingan yang sangat ketat dengan produk serupa dapat terjadi pada tahap ini sehingga diferensiasi produk menjadi hal yang esensial bagi perusahaan agar tetap mampu bersaing dengan produk kompetitor. Terakhir adalah tahap penurunan (decline). Pada tahap ini penjualan produk akan benarbenar menurun hingga titik terendah. Ketika berada pada tahap ini maka pilihan yang dapat ditempuh perusahaan sebelum benar-benar menghentikan produk adalah antara lain dengan melakukan pembaharuan.

Persaingan yang semakin ketat seiring dengan semakin tingginya tingkat kedewasaan suatu produk kadang membuat perusahaan perlu untuk melakukan rebranding. Rebranding sendiri merupakan upaya yang dilakukan oleh perusahaan atau lembaga untuk mengubah total atau memperbaharui brand perusahaan agar menjadi lebih baik dengan tidak meninggalkan tujuan awal dari perusahaan itu sendiri (Prayudi dan Juanita, 2005: 166). Rebranding bagi sebuah perusahaan berfungsi untuk merepresentasikan perubahan posisi brand di benak pemilik kepentingan dan sebagai identitas pembeda dengan pesaing (Muzellec, dkk, 2003: 32)

Rebranding sendiri bukan lah merupakan hal yang baru di lingkungan bisnis. Banyak industri yang memutuskan untuk melakukan rebranding sebagai strategi yang dipilih, termasuk industri di bidang media massa. Salah satu media massa lain yang tidak lepas dari kebutuhan akan rebranding adalah radio. Berdasarkan temuan Nielsen.com pada tahun 2014, radio menempati urutan ketiga setelah televisi dan internet sebagai media yang paling utama dikonsumsi oleh masyarakat Indonesia. Seperti dilansir dari situs milik Direktorat Politik dan Komunikasi, untuk provinsi Jawa Barat terdapat lebih dari 60 stasiun radio dimana 30 diantaranya merupakan stasiun radio yang beroperasi di wilayah Kota Bandung.

Dengan banyaknya jumlah stasiun radio yang beroperasi di Bandung, jelas merupakan tantangan bagi masing-masing stasiun untuk mampu bersaing merebut pasar pendengar. Salah satu strategi agar tetap dapat bertahan di industri bisnis adalah dengan melakukan rebranding. Salah satu radio yang kemudian memutuskan untuk melakukan rebranding adalah Zora Radio yang beralamat di Jln. Sumur Bandung No. 12. Zora Radio yang awalnya merupakan radio yang memiliki segmen dewasa muda di awal tahun 2014 memutuskan untuk melakukan rebranding dengan mengusung slogan baru yakni Enjoy The Beat, dan memilih segmen remaja hingga dewasa muda di bulan Oktober 2014. Rebranding ini ditandai dengan perubahan visi dan misi baru untuk menjadi radio muda yang mengedepankan nilai edutainment dan sinergi dengan komunitas positif yang diwujudkan melalui rebranding menyeluruh mulai dari logo, warna, slogan, juga program siaran.

Sebagai perbandingan peneliti mengemukakan penelitian yang dilakukan oleh Priyatmoko yang menjelaskan:

"Branding merupakan salah satu unsur 
pentingdalamstrategipemasaranpariwisata, karena merepresentasikan kualitas dari produk-produk wisata yang akan dijual kepada wisatawan. Pramuwisata sebagai salah satu elemen yang berada di garda depan dalam bisnis pariwisata diharapkan mempunyai tingkat kesadaran merek (brand awareness) yang tinggi terhadap kedua branding Wonderful Indonesia dan Pesona Indonesia” (Priyatmoko, 2016).

Untuk memaksimalkan nilai-nilai dan visi yang diusung dengan melakukan rebranding saat ini, berbagai strategi pun diterapkan oleh Zora Radio agar proses perubahan yang dilakukan berjalan dengan lancar dan sesuai dengan yang diharapkan. Berdasarkan uraian latar belakang di atas, maka penulis tertarik untuk melakukan penelitian dengan judul "Strategi Rebranding Zora Radio". Adapun fokus penelitian dalam penelitian ini adalah bagaimana strategi rebranding dari Zora Radio dengan melihatnya melalui tiga tahapan utama yaitu tahap perencanaan, tahap implementasi, dan tahap evaluasi.

\section{METODE PENELITIAN}

Paradigma penelitian merupakan seperangkat konsep, keyakinan, asumsi, nilai, metode, atau aturan yang membentuk kerangka kerja pelaksanaan sebuah penelitian. Paradigma membantu merumuskan apa yang harus dipelajari, pertanyaan-pertanyaan apa yang harus diajukan, dan aturan-aturan apa yang harus diikuti dalam menafsirkan jawaban yang diperoleh (Ikbar, 2012: 51). Paradigma penelitian yang digunakan dalam penelitian ini adalah paradigma penelitian konstruktivisme sosial. Konstruktivisme sosial meneguhkan asumsi bahwa individu-individu selalu berusaha memahami dunia di mana mereka hidup dan bekerja. Mereka mengembangkan makna-makna subjektif atas pengalamanpengalaman mereka, makna-makna yang diarahkan pada objek-objek atau bendabenda tertentu (Creswell, 2014: 11). Dalam penelitian ini peneliti menggunakan paradigma konstruktivisme karena peneliti ingin mencari dan memahami pandangan-pandangan informan mengenai strategi rebranding pada Zora Radio.

Penelitian ini menggunakan metode penelitian kualitatif. Penelitian kualitatif merupakan metode untuk mengeksplorasi dan memahami makna yang berasal dari masalah sosial atau kemanusiaan. Proses penelitian kualitatif ini melibatkan upaya-upaya penting, seperti mengajukan pertanyaan-pertanyaan dan prosedur-prosedur, mengumpulkan data yang spesifik dari para partisipan, menganalisis data secara induktif mulai dari tema-tema yang khusus ke tema-tema umum, dan menafsirkan makna data. Laporan akhir untuk peneltian ini memiliki struktur atau kerangka yang fleksibel. Siapa pun yang terlibat dalam bentuk penelitian ini harus menerapkan cara pandang penelitian yang bergaya induktif, berfokus terhadap makna individual, dan menerjemahkan kompleksitas suatu persoalan (Creswell, 2014: 4). Menurut Sugiyono (dalam Mulyawan, 2012: 8) metode penelitian kualitatif digunakan untuk mendapatkan data yang mendalam, suatu data yang mengandung makna. Makna adalah data yang sebenarnya. Data yang pasti merupakan suatu nilai di balik data yang tampak.

Adapun metode yang digunakan dalam penelitian ini adalah studi kasus. Stake (dalam Creswell, 2014: 20) menjelaskan studi kasus merupakan metode penelitian dimana didalamnya peneliti menyelidiki secara cermat suatu program, peristiwa, aktivitas, proses, atau sekelompok individu. Kasus-kasus dibatasi oleh waktu dan aktivitas, dan peneliti mengumpulkan informasi secara lengkap dengan menggunakan berbagai prosedur pengumpulan data berdasarkan waktu yang telah ditentukan.

Analisis data adalah proses mencari dan menyusun secara sistematis data yang diperoleh dari hasil wawancara, catatan lapangan, dan dokumentasi dengan cara mengorganisasikan data ke dalam kategori, menjabarkan ke dalam unit-unit, melakukan sintesis, menyusun ke dalam pola, memilih mana yang penting dan yang akan dipelajari, dan membuat kesimpulan sehingga mudah dipahami oleh diri sendiri maupun orang lain (Sugiyono, 2014: 89).

Analisis data dalam penelitian kualitatif berlangsung selama proses pengumpulan data sampai dengan selesai pengumpulan data. 
Adapun proses dalam analisis data ini dilakukan dalam tiga tahapan yaitu analisis sebelum di lapangan, analisis selama di lapangan (Model Miles and Huberman) dan Analisis data selama di lapangan model Spradley (Sugiyono, 2014: 90). Penelitian kualitatif telah melakukan analisis data sebelum peneliti memasuki lapangan. Analisis dilakukan terhadap data hasil studi pendahuluan, atau data sekunder, yang akan digunakan untuk menentukan fokus penelitian. Fokus penelitian ini bersifat sementara dan berkembang setelah peneliti masuk dan selama di lapangan.

Analisis data dalam penelitian kualitatif, dilakukan pada saat pengumpulan data berlangsung, dan setelah selesai pengumpulan data dalam periode waktu tertentu. Pada saat wawancara, peneliti sudah melakukan analisis terhadap jawaban yang diwawancarai. Bila jawaban yang diwawancarai setelah dianalisis terasa belum memuaskan, maka peneliti akan melanjutkan pertanyaan lagi, sampai tahap tertentu, diperoleh data yang dianggap kredibel. Miles and Huberman (dalam Sugiyono, 2014: 91) mengemukakan aktivitas dalam analisis data kualitatif ke dalam tiga tahapan yaitu: (1) Data Reduction (Reduksi Data). Data yang diperoleh dari lapangan jumlahnya cukup banyak, untuk itu maka perlu dicatat secara teliti dan rinci. Seperti telah dikemukakan, semakin lama peneliti ke lapangan, maka jumlah data akan semakin banyak, kompleks dan rumit. Untuk itu perlu segera dilakukan analisis data melalui reduksi data. Mereduksi data berarti merangkum, memilih hal-hal yang pokok, memfokuskan pada hal-hal yang penting, dicari tema dan polanya. Dengan demikian data yang telah direduksi akan memberikan gambaran yang lebih jelas, dan mempermudah peneliti untuk melakukan pengumpulan data selanjutnya, dan mencarinya bila diperlukan, (2) Data Display (Penyajian Data). Setelah data direduksi, maka langkah selanjutnya adalah penyajian data. Yang paling sering digunakan dalam untuk menyajikan data dalam penelitian kualitatif adalah dengan teks ayng bersifat naratif. Dengan menyajikan data, maka akan memudahkan untuk memahami apa yang terjadi, merencanakan kerja selanjutnya berdasarkan apa yang telah dipahami tersebut, dan (3) Conclusing Drawing/Verification. Langkah ketiga dalam analisis data kualitatif menurut Miles and Huberman adalah penarikan kesimpulan dan verifikasi. Kesimpulan awal yang dikemukakan masih bersifat sementara, dan akan berubah bila tidak ditemukan buktibukti yang kuat dan mendukung pada tahap pengumpulan data berikutnya. Tetapi apabila kesimpulan yang dikemukakan pada tahap awal, didukung oleh bukti-bukti yang valid dan konsisten saat peneliti kembali ke lapangan mengumpulkan data, maka kesimpulan yang dikemukakan merupakan kesimpulan yang kredibel.

Proses penelitian kualitatif setelah memasukilapangan, dimulaidenganmenetapkan seorang informan kunci "key informant" yang merupakan informan yang berwibawa dan dipercaya mampu "membukakan pintu" kepada peneliti untuk memasuki objek penelitian. Setelah itu peneliti melakukan wawancara kepada informan tersebut, dan mencatat hasil wawancara. Setelah itu perhatian peneliti pada objek penelitian dan dan memulai mengajukan pertanyaan deskriptif, dilanjutkan dengan analisis terhadap hasil wawancara.

\section{HASIL DAN PEMBAHASAN}

Dari hasil penelitian dalam proses rebranding yang dilakukan oleh Zora Radio Bandung, dapat diketahui kegiatan rebranding dan strategi rebranding Zora Radio yang diterapkan melalui tiga tahapan utama, yaitu tahap perencanaan, tahap implementasi, dan tahap strategi.

Per Oktober 2014, Zora Radio yang tadinya mengusung slogan Fresh and Hits melakukan rebranding dengan mengusung slogan baru yaitu Enjoy The Beat. Penggantian slogan ini diikuti juga dengan berbagai perubahan lainnya dalam lingkup internal perusahaan untuk menegaskan identitas merek baru yang dimiliki oleh Zora Radio.

Perubahan krusial ini disebabkan karena Zora Radio memilih untuk mengubah segmentasi pendengarnya. Menginjak tahun ke-2 sejak melakukan rebranding menjadi radio muda, Zora Radio dapat dikatakan telah mampu 
menarik perhatian banyak pihak terutama pendengar yang menjadi pangsa pasar utamanya dalam proses rebranding ini. Zora Radio telah mampu mencapai tujuan utamanya yakni untuk mendapatkan pendengar dari segmentasi anak muda sebagai segmen yang dipilih. Adapun proses rebranding ini dilakukan melalui tiga tahapan utama sebagai berikut:

Sebelum memulai untuk menetapkan strategi yang tepat dalam proses rebranding Zora Radio, tahapan pertama yang dilakukan adalah dengan membuat perencanaan-perencanaan yang terstruktur sehingga rebranding dapat berjalan dengan lancar dan sesuai dengan yang diharapkan. Langkah pertama yang dilakukan oleh Zora Radio adalah dengan menetapkan goals atau tujuan terlebih dahulu. Tujuan yang dimaksud adalah sesuatu yang ingin dibentuk oleh Zora Radio melalui proses rebranding ini. Tujuan ini tercantum di dalam visi dan misi yang baru dengan penerjemahan melalui rencana kerja perusahaan. Bagi Zora Radio sendiri proses ini tidak dilakukan dengan begitu formal dan terkesan kaku seperti yang seharusnya dilakukan oleh perusahaan pada umumnya, namun hanya sekedar menetapkan tujuan dan berusaha mewujudkannya melalui aktivitas-aktivitas yang berkaitan dengan proses rebranding.

"Tingkat dan jenis kebutuhan serta keinginan konsumen itu dapat berbeda satu dengan yang lainnya, yang ini menyebabkan pilihan terhadap terbukanya usaha bisnis peluangnya menjadi semakin banyak dan besar, alasan pemilihan atau tujuan pemilihan dan faktor-faktor yang harus dipertimbangkan dalam suatu usaha berbisnis pada setiap konsumen juga berbeda. Selain itu, menentukan segmen mana pangsa pasar berada dan mengindentifikasikan konsumen ke dalam segmen-segmen tertentu serta mengindentifikasi target apa yang dicapai dan positioning-nya" (Hartono, Hutomo, \& Mayangsari, 2012).

Tujuan yang ingin dicapai oleh Zora sendiri adalah untuk menjadi radio muda yang sinergi dengan nilai edukasi dan komunitas positif. Oleh karena itu, semua elemen yang berada di tubuh Zora Radio dibuat untuk mengarah ke tujuan tersebut. Mengetahui dan menetapkan tujuan dari strategi merupakan hal yang penting untuk dapat melanjutkan ke tahap berikutnya dalam proses rebranding ini.

Setelah melakukan penetapan tujuan selanjutnya adalah menetapkan segmenting, targeting, dan positioning perusahaan. Meskipun segmenting, targeting, dan positioning telah ditetapkan sejak awal tahun 2014, namun melalui rebranding ini yang dilakukan oleh Zora Radio adalah hanya mempertajam segmenting, targeting, dan positioning yang telah dibentuk.

Perubahan yang krusial terkait dengan hal ini kemudian sangat mempengaruhi Zora Radio dalam memutuskan pembuatan programprogram siarannya. Selain menetapkan tujuan, Zora Radio juga melakukan analisis-analisis yang berkaitan dengan kinerja dan rencana kerja perusahaan untuk kedepannya. Dalam hal ini Zora melakukan antara lain analisis Strength, Weakness, Opportunities, and Threats (SWOT) serta analisis kompetitor meskipun diakui tidak dilakukan secara mendalam melainkan hanya untuk mendapatkan gambaran perusahaan akan dibawa ke arah mana.

Meskipun tidak dilakukan analisis secara khusus dan mendalam, namun Zora Radio sudah mampu mengerucutkan nilai dan potensi yang dimiliki oleh perusahaan menjadi suatu benang merah yang diwujudkan ke dalam bentuk pola perusahaan yang baru. Visi dan misi untuk menjadi radio muda yang tidak hanya memiliki nilai edukasi dan hiburan namun juga mampu bersinergi dengan komunitas positif menjadi nilai tambah yang membedakan Zora Radio dengan radio-radio lain yang sejenis, sehingga setiap program yang dibuat oleh Zora Radio selain untuk memberikan edukasi dan hiburan ringan, namun juga harus selaras dengan berbagai komunitas positif. Misalnya, Zora memiliki program dengan nama Seoul Time. Seoul Time merupakan program acara yang membahas segala sesuatu mengenai Korea, mulai dari musik, budaya, drama, film, dll. Harapannya adalah untuk mampu meraih pasar pecinta Korea. Selain itu Zora Radio juga memiliki program-program lain yang masingmasing program tersebut dikhususkan untuk 
komunitas-komunitas positif sebagai upaya kolaborasi.

Kemudian hal lain yang dilakukan oleh Zora Radio adalah dengan mempertimbangkan penerapan-penerapan strategi tersebut melalui rencana jangka waktu dari strategi yang diterapkan. Zora Radio memliki tiga jangka waktu yang dipertimbangkan yakni jangka pendek, jangka menengah, dan jangka panjang untuk strategi-strateginya.

Penerapan jangka pendek dilakukan dengan mempertimbangkan bagaimana strategi rebranding yang diterapkan dapat mempercepat pemasukan yang didapat oleh Zora Radio. Untuk mempercepat pemasukan yang diterima Zora Radio hal yang dilakukan adalah mendapatkan pendengar sebanyak-banyaknya. Untuk jangka menengah target Zora Radio adalah untuk merubah habit atau kebiasaan orang-orang yang membawa brand Zora agar brand soul masuk dan dapat ditemukan di diri orang-orang tersebut. Jangka panjang berkaitan dengan bagaimana nilai yang ditawarkan oleh Zora dapat ditransfer dan diterima dengan baik oleh pendengar. Ketiga karakterisitik strategi ini digunakan oleh Zora Radio dan diwujudkan dalam bentuk pengimplementasian strategi rebranding yang dilakukan secara bertahap.

Implementasi strategi rebranding Zora Radio dilakukan secara bertahap dan hampir ke seluruh elemen dalam perusahaan sendiri. Hal yang paling mendasar adalah perubahan pada positioning yang dipilih oleh Zora. Visi dan misi perusahaan yang baru sangat tercermin dalam positioning yang ditekankan pada sinergitas dengan komunitas positif, sehingga Zora Radio pun melakukan perubahan-perubahan pada program siaran untuk mengikuti hal tersebut.

Perwujudan dari keinginan untuk membentuk radio yang memiliki sinergi

Tabel 1 Zora Radio Sebelum dan Setelah Rebranding

\section{Elemen

Logo

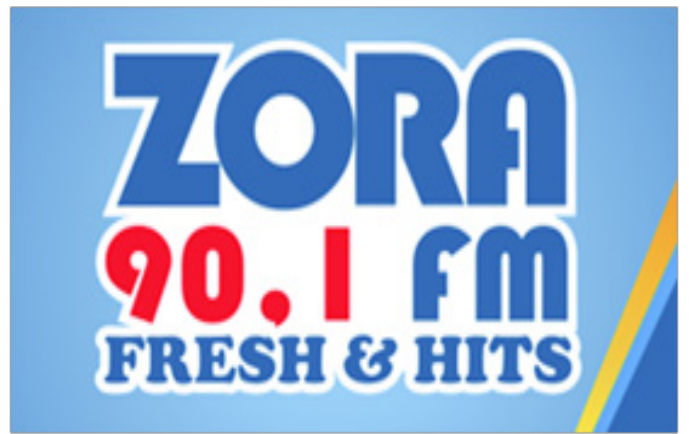

Fresh \& Hits

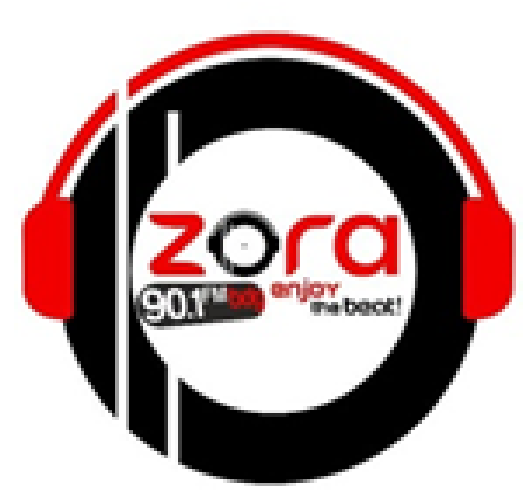

Enjoy The Beat
Tagline

Format acara

Format musik
$80 \%$ Musik, 20\% Info tips, talkshow, quiz

Edutainment, komunitas, lifestyle
45\% Internasional, 45\% Indonesia, $10 \%$ Asia 
dengan komunitas positif dan menjunjung nilai edukasi dan hiburan dibentuk dengan membuat program-program radio yang selaras dengan tujuan-tujuan tersebut. Misalnya, program Seoul Time yang dikhususkan bagi penyuka Korea, program Japan Beats bagi penyuka Jepang, Zora Indie Air bagi komunitas penikmat music indie, dll. Keseluruhan program acara dibuat untuk menjadi wadah bagi komunitaskomunitas tersebut untuk berbagi dan berkarya. Dalam menentukan pembuatan sebuah programpun tidak terlepas dari serangkaian pertimbangan yang perlu dilakukan oleh bagian yang bertanggung jawab terhadap program, agar program yang dibuat tidak hanya sekedar menarik dari segi pengemasan maupun konsep, namun juga dapat memuat nilai-nilai yang menjadi tujuan dari Zora Radio.

Selain program acara yang mengalami perubahan secara keseluruhan, yang juga mengalami perubahan adalah aspek-aspek fisik yang dapat terlihat dan mudah untuk disadari oleh pihak eksternal Zora Radio. Namun berbeda dengan proses rebranding pada umumnya yang identik dengan perubahan nama perusahaan, Zora Radio memilih untuk tidak melakukan penggantian nama dan tetap memilih nama Zora yang sudah digunakan sejak awal berdirinya. Berkaitan dengan hal ini, alasan untuk mempertahankan nama Zora dinilai untuk menjaga nilai historis dari Zora Radio sendiri. Meskipun Zora Radio tidak mengubah nama, Zora Radio melakukan perubahan terhadap logo, warna, serta slogan yang diusung. Perubahan-perubahan ini juga diikuti dengan perubahan pada aspek fisik perusahaan yang dapat dengan mudah diketahui oleh pihak eksternal, salah satu contohnya adalah OB Van. Adapun jika dibandingkan dengan konsep yang dahulu dimiliki, proses rebranding dilakukan oleh Zora Radio dapat dilihat melalui tabel 1.

Setelah melakukan berbagai upaya rebranding, hal yang juga dilakukan adalah dengan melakukan sosialisasi dari proses rebranding ini kepada seluruh khalayak Zora Radio terutama pihak eksternal, karena memang sasaran dari proses rebranding ini adalah semua pihak, baik internal aupun eksternal. Sosialisasi rebranding dilakukan oleh Zora Radio dengan berbagai cara. Terhadap pihak internal, Zora Radio tidak dilakukan sosialisasi secara khusus melainkan semua individu didalamnya harus langsung mengimplementasikan proses rebranding ke tugas kerja masing-masing dengan tujuan agar proses rebranding di lingkup internal perusahaan berlangsung dengan lebih cepat dan efektif.

Berbeda dengan proses sosialisasi rebranding terhadap pihak eksternal. Dalam sosialisasi terhadap pihak eksternal, Zora Radio belum begitu banyak melakukan aktivitas di luar karena terkendala budgeting. Namun beberapa perencanaan sudah dapat dijalankan di sepanjang akhir tahun 2015 hingga saat ini. Salah satu yang gencar dilakukan oleh Zora Radio adalah dengan menggunakan jasa endorser. Bentuk endorsement ini diwujudkan Zora Radio dengan menggelar event-event yang menghadirkan artis-artis yang mengendorse Zora Radio sendiri. Strategi ini pun diterapkan setiap bulannya, di mana endorser Zora Radio berubah setiap bulannya.

Hal yang juga dilakukan oleh Zora Radio adalah dengan agresif mendekati target pasar yang dituju. Karena saat ini Zora Radio memilih segmentasi dan target anak muda yang memang berada di usia sekolah dan kuliah, maka pendekatan yang Zora lakukan adalah dengan mendatangi sekolah-sekolah dan kampuskampus yang berada di wilayah Bandung serta memasang banner atau baliho di sekitar wilayah tersebut untuk memperkenalkan Zora Radio.

Tidak cukup dengan itu saja Zora Radio dalam melakukan sosialisasi mengenai rebranding dengan cara menjalin kerjasama dengan pihak ketiga, dengan tujuan menjalin hubungan yang saling menguntungkan bagi kedua belah pihak. Selain itu usaha lain yang dilakukan adalah dengan menggelar event-event kecil yang melibatkan komunitas-komunitas tertentu.

Selain sebagai bukti kesungguhan Zora Radio untuk mewujudkan visi dan misi dalam mengedepankan komunitas positif dan edukatif, hal ini juga dilakukan sebagai upaya mengenalkan merek baru Zora Radio kepada khalayak luas. Semua usaha sosialisasi rebranding yang dilakukan oleh Zora ini 
Gambar 1 Tahap Perencanaan Strategi Rebranding Zora Radio

Sumber: Penelitian, 2015

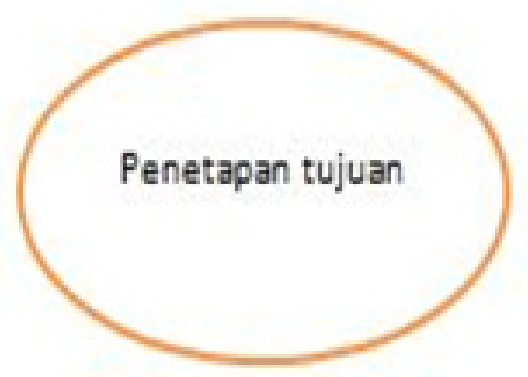

Tahap Perencanaan

Strategi Rebranding Zora

Radio
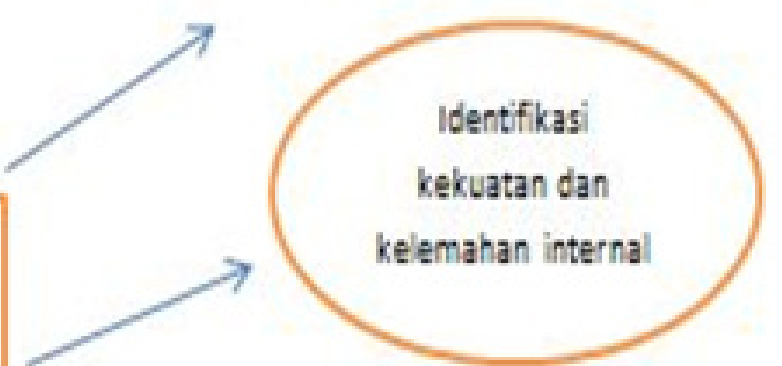

dentifikasi peluang

dan ancaman

eksternal

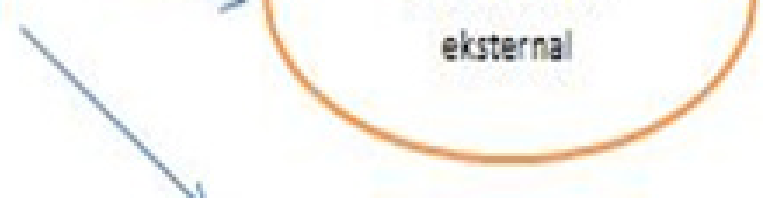

Penetapan jangka

waktu

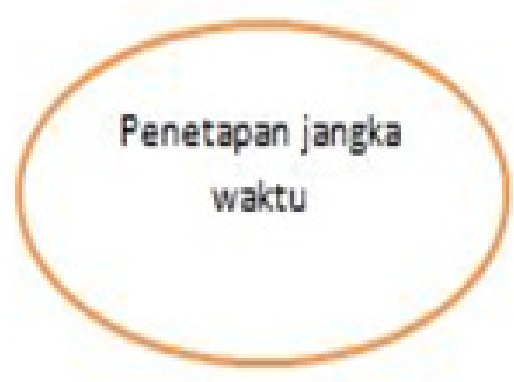

memiliki satu tujuan yang sama, bahwa hal tersebut ditujukan untuk meningkatkan awareness khalayak luas terhadap keberadaan Zora Radio yang baru.

Setelah strategi rebranding telah diimplementasikan, selanjutnya adalah bagaimana upaya Zora Radio dalam melakukan evaluasi terhadap strategi yang telah diterapkan. Bagi Zora Radio sendiri evaluasi dilakukan oleh direktur melalui feedback dari bawahan, konsumen (pengiklan), serta pendengar dengan melalui jasa survei AC Nielsen dan media sosial milik Zora Radio. Setelah feedback-feedback seperti ini didapatkan maka akan dapat diketahui bagaimana hasil kerja dalam penerapan strategi rebranding tersebut untuk selanjutnya dapat dilakukan penyesuaian terhadap perencanaan strategi atau implementasi strategi, atau keduanya.

Pada hakikatnya, strategi dalam pengertian khusus merupakan tindakan yang bersifat senantiasa meningkat, terus-menerus dilakukan berdasarkan sudut pandang tentang apa yang diharapkan pelanggan di masa depan (Sedarmayanti, 2014: 2). Strategi rebranding yang dilakukan oleh Zora Radio dilakukan dengan harapan Zora Radio dapat memenuhi keinginan dan kebutuhan pasar akan sebuah 
radio yang tidak hanya memiliki nilai edukasi dan hiburan yang menarik, namun juga mampu bersinergi dengan komunitas positif sekaligus menjadi wadah bagi komunitas-komunitas tersebut untuk terus berkarya. Dengan hal itu kemudian tujuan untuk meraih pangsa pendengar sebanyak-banyaknya akan dapat diwujudkan. Penerapan strategi ini dilakukan dalam tiga tahapan utama yaitu perencanaan, implementasi, dan evaluasi.

Sebelum menetapkan strategi, proses awal yang dilalui oleh Zora Radio adalah dengan melakukan perencanaan strategi atau sering juga disebut perumusan strategi. Perumusan
Pada tahap Implementasi Strategi Rebranding, strategi yang dibentuk di tahap perencanaan kemudian diimpelementasikan dalam praktik nyatanya. Tahap penerapan strategi sering juga dikenal dengan tahap aksi. Pada Zora Radio sendiri penerapan strategi diwujudkan ke dalam suatu proses rebranding yang utuh dan terstruktur. Ada empat elemen penting yang membentuk suatu proses rebranding. Elemen-elemen tersebut adalah repositioning, renaming, redesigning, dan relaunching (Muzellec, dkk, 2003: 34).

Repositioning adalah keputusan yang diambil perusahaan untuk membentuk posisi

\section{Gambar 2 Tahap Implementasi Strategi Rebranding Zora Radio}

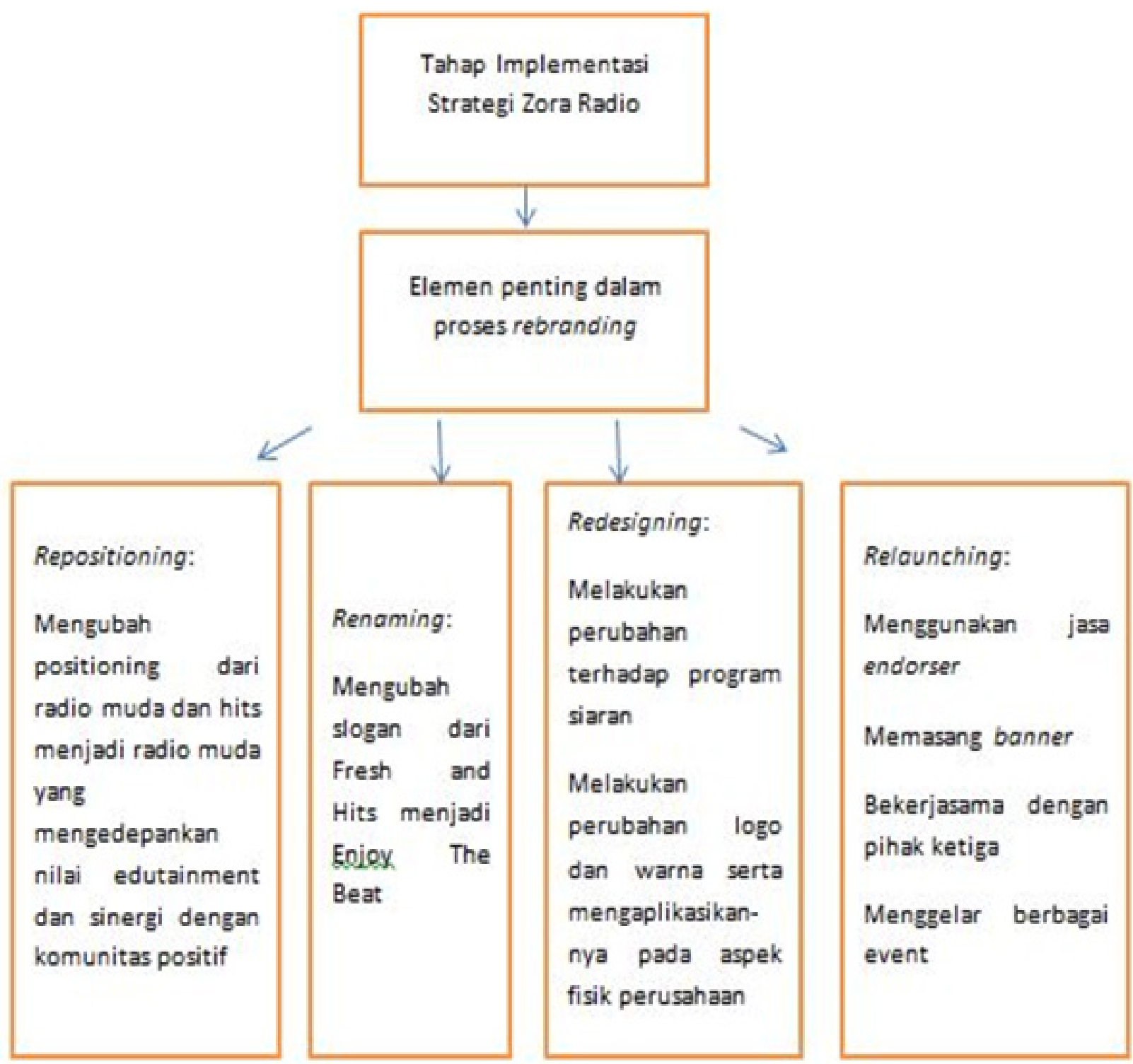

Sumber: Penelitian, 2015 
baru bagi perusahaan di benak konsumen, pesaing, dam pemilik kepentingannya (Ries and Trout dalam Muzellec, dkk, 2003: 34). Repositioning Zora Radio mengalami perubahan dari yang tadinya radio muda dan hits, menjadi radio muda yang mengedepankan nilai edutainment dan sinergi dengan komunitas positif. Dekat dengan komunitas-komunitas positif menjadi positioning yang ditekankan oleh Zora Radio.

Pemberian nama kembali bagi (renaming) perusahaan terkadang dilakukan untuk mengirim signal kepada pemilik kepentingan bahwa perusahaan sedang melakukan perubahan, baik dari strategi maupun kepemilikan perusahaan. Pada tahap ini perubahan juga terjadi pada slogan perusahaan. (Muzellec, dkk., 2003: 34). Meskipun Zora Radio tidak melakukan perubahan nama, namun proses renaming tetap terjadi karena Zora Radio melakukan perubahan slogan yakni dari Fresh and Hits menjadi Enjoy The Beat.

Selain nama dan slogan, logo juga menjadi salah satu elemen penting yang membentuk sebuah merek. Redesign dilakukan terhadap semua elemen yang tampak pada perusahaan, misalnya alat-alat tulis, brosur, iklam, laporan tahunan, kantor, serta elemen-elemen lain yang dapat terlihat (Muzellec, dkk, 2003: 35). Dalam hal ini, Zora Radio melakukan perubahan logo dan warna dan kemudian mengaplikasikannya ke dalam aspek lain perusahaan yang dapat terlihat, misalnya OB Van. Selain logo, elemen lain yang dapat dengan mudah langsung terlihat atau dirasakan adalah program-program siaran. Proses rebranding yang dilakukan juga membuat Zora Radio mengubah semua program siarannya agar sesuai dengan visi dan misi baru yang diusung.

Relaunch adalah tahap terakhir, dimana pada tahap ini dilakukan usaha untuk mengkomunikasikan perubahan yang dilakukan kepada publik agar membentuk kesadaran (Muzellec, dkk, 2003: 35). Tujuan dari proses ini adalah membuat khalayak dari Zora Radio menjadi sadar akan merek baru yang ditawarkan oleh Zora Radio. Hal-hal yang dilakukan oleh Zora Radio dalam memngkomunikasikan rebranding yang dilakukan kepada khalayak luar antara lain dengan melakukan endorsement, memasang banner, bekerja sama dengan pihak ketiga, serta menggelar event-event menarik.

Tahap evaluasi merupakan tahap terakhir dan pada tahap ini dilakukan penilaian mengenai strategi yang telah diterapkan. Tiga aktivitas yang mendasar adalah peninjauan ulang faktor

\section{Gambar 3 Tahap Evaluasi Strategi Rebranding Zora Radio}

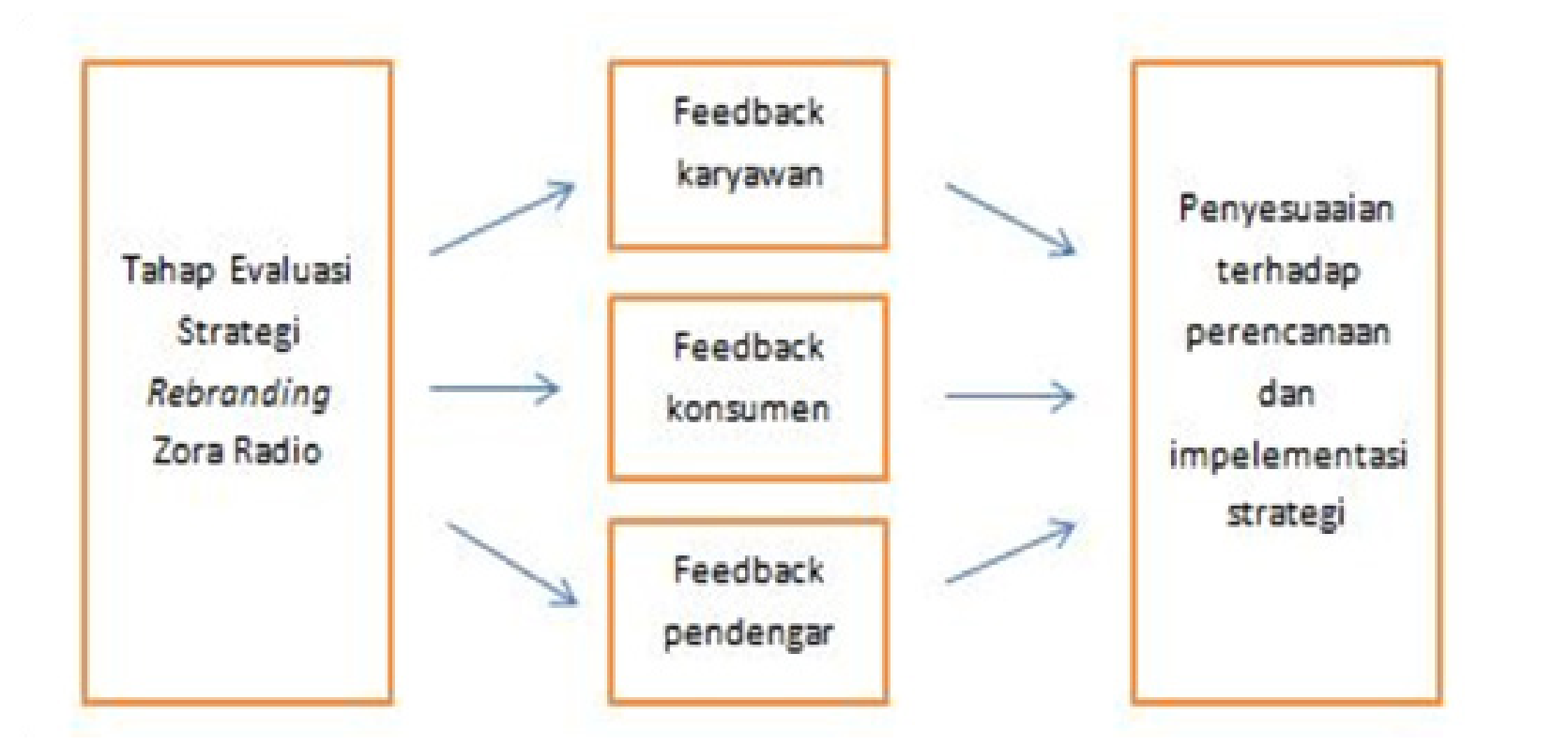

Sumber: Penelitian, 2015 
eksternal dan internal yang menjadi landasan bagi strategi saat ini, pengukuran kinerja, dan pengambilan langkah korektif (Sedarmayanti, 2014: 12).

Evaluasi oleh Zora Radio bertujuan untuk mengukur apakah strategi rebranding yang dilakukan berjalan dengan lancar dan sesuai dengan goals yang telah ditentukan sebelumnya melalui usaha untuk mendapatkan feedback dari berbagai pihak. Direktur Zora Radio selaku pemegang tanggung jawab dalam penerapan strategi rebranding meminta feedback dari karyawan dan penyiar, konsumen atau pengiklan yang menggunakan jasa Zora Radio, dan pendengar melalui pemantauan terhadap hasil survei AC Nielsen serta akun media sosial Zora Radio. Dari hasil feedback ini maka dapat ditentukan langkah selanjutnya terkait penyesuaian strategi baik dalam hal perencanaan maupun implementasinya.

\section{SIMPULAN}

Tahap Perencanaan strategi rebranding oleh Zora Radio dilakukan dengan menetapkan tujuan yang ingin dicapai oleh perusahaan, melakukan identifikasi terhadap kekuatan dan kelemahan internal perusahaan serta identifikasi peluang dan ancaman eksternal yang dihadapi perusahaan, dan menentukan jangka waktu terhadap setiap strategi yang akan diterapkan.

Tahap Implementasi Strategi rebranding Zora Radio Implementasi dari strategi diwujudkan melalui empat elemen utama rebranding yaitu renaming, repositioning, redesigning, dan relaunching.

Tahap Evaluasi Strategi Rebranding Zora Radio dilakukan dengan memantau feedback yang diperoleh dari berbagai pihak yaitu karyawan, konsumen atau pengiklan, serta pendengar. Hasil feedback ini kemudian dijadikan pedoman perusahaan dalam melakukan penyesuaian terhadap perencanaan dan implementasi strategi selanjutnya.

Berdasarkan kesimpulan yang diperoleh dalam penelitian ini, maka saran akademis yang peneliti berikan adalah agar peneliti selanjutnya tidak hanya sekedar memaparkan strategi rebranding yang dilakukan oleh suatu perusahaan saja, namun juga diharapkan mampu melakukan analisis yang lebih mendalam agar dapat ditemukan strategi yang lebih tepat untuk digunakan oleh perusahaan yang bersangkutan.

Saran yang dapat peneliti berikan kepada pihak Zora Radio berkaitan dengan tahap evaluasi. Hasil evaluasi dapat dijadikan pedoman dalam melakukan proses sosialisasi atau komunikasi kepada khalayak luas mengenai strategi rebranding yang sudah diimplementasikan. Selanjutnya sosialisasi sebaiknya dilakukan secara lebih luas dan massive agar penyampaian nilai dan pesan yang diusung oleh Zora Radio melalui proses rebranding ini dapat diterima dengan lebih cepat oleh khalayak sehingga dapat terbentuk awareness terhadap wajah baru dari Zora Radio.

\section{DAFTAR PUSTAKA}

Creswell, J. W. (2014). Research designed pendekatan kualitatif dan mixed. Yogyakarta: Pustaka Pelajar

Hartono, H., Hutomo, K., \& Mayangsari, M. (2012). Pengaruh strategi pemasaran terhadap peningkatan penjualan pada perusahaan" dengan menetapkan alumni dan mahasiswa universitas bina nusantarasebagai objek penelitian. Jurnal Binus Business Review Vol 3, 882-897

Ikbar, Y. (2012). Metode penelitian sosial kualitatif. Bandung: Refika Adikana

Mulyawan, A. (2012). Strategi komunikasi pemasaran trans studio bandung dalam menumbuhkan minat konsumen untuk berkunjung. eJournal mahasiswa universitas padjadjaran Vol. 1, No. 1. Diakses dari https: //jurnal.unpad.ac.id/ ejournal/article/view/1849/pdf_36 tanggal 29 Mei 2016

Muzellec, L. Doogan, M. \& Lambkin, M. (2003). Corporate rebranding: an exploratory review. Irish Marketing Review. Vol. 16 No. 2 pp. 31. Diakses dari https://search.proquest.com/openview/77c f46f50763da640e552d1d2dea72d0/1?pqorigsite $=$ gscholar $\&$ cbl $=30722$

Prayudi \& Juanita. (2005). Strategic corporate communication dalam proses repositioning dan rebranding. Jurnal Ilmu Komunikasi Yogyakarta Vol.2No.2 pp.159-176. Diakses 
dari http://www.e-jurnal.com/2014/05/ strategic-corporate-communication-dalam. html

Priyatmoko, R. (2016). Tingkat kesadaran pramuwisata terhadap branding wonderful indonesia dan pesona indonesia: strategi pemasaran destinasi pariwisata. Jurnal
Destinasi Kepariwisataan Indonesia Vol 1, 83-102

Sedarmayanti. (2014). Manajemen strategi. Bandung: Refika Aditama

Sugiyono. (2014). Memahami penelitian kualitatif. Bandung: Alfabeta 